scheme for a system of agricultural education in Great Britain, and this is urgently needed. It was suggested by Mr. F. R. Horne, of Devon, that not enough attention has been paid to following up the careers of the more promising trainees to see that they become established in agriculture.

The technical development sub-committees referred to in Mr. Garner's paper were both criticized and praised. They were spoken of as an implied criticism of pre-war policy in agricultural education, because if this had not been neglected in pre-war years, there would not now be the necessity for forming these committees. The work of these committees was also stated not to be fundamental education but rather 'tip-giving'. On the other hand, the expansion of agricultural education through the committees as a national charge was welcomed, and it was urged that if they are to continue after the War they must be moulded on the right lines now.

A statement by Mr. R. C. Andrew on the Danish system of education for older people caused Mr. R. C. Wood to urge his hearers to familiarize themselves with the writings of Sir Richard Livingstone on the Danish folk high schools. More attention must be paid to adult education and a more cultural atmosphere should be introduced into agricultural institutions in Great Britain.

\section{NORTH SYRIA AS A CULTURAL LINK IN THE ANCIENT WORLD}

7 HE subject chosen by Sir Leonard Woolley for his Huxley Memorial Lecture delivered on November 24 before the Royal Anthropological Institute was the role played by north-west Syria in the first and second millennia B.C. as a connecting link between the civilizations of the Near and Middle East. The region is defined as the area stretching from Lattakia on the present north Syrian coast northwards to the Anti-Taurus Range, and from the Mediterranean Sea to Aleppo. To the south and south-east lay "the commercial kingdoms of Syria and the Phoenician harbours", with Egypt still farther to the south; eastwards lay the homes of the Amorites and the Khurri, leading on to Nineveh. The Euphrates leads direct to Babylon or northeastwards to the region of Lake Van and the Uratu kingdom; northwards beyond the mountain barriers lay Cappadocia and the Konia plain, leading to the Bosphorus or the Ionian coast; westwards were Crete and Greece, with Cyprus-actually visible from the top of Mount Casius-as a stepping-stone. The nodal position of the region thus chosen is obvious.

Before the War, three main excavations of special interest from Sir Leonard's point of view were in progress: Ras Shamra, just north of Lattakia, the ancient royal city of Ugarit; Al Mina, at the mouth of the Orontes, and the Atchana mound, up the Orontes on the edge of the great Amk plain; and Tal Tayanat, where the Oriental Institute of Chicago has excavated the Syro-Hittite palace. Other recent excavations there have of course been in the Amk plain, and also farther north-westwards as at Mersin on the Cilician coast, but Sir Leonard in the limited time available confined himself principally to the results of his own work at Atchana where, too, the chronological framework devised by Prof. Sidney
Smith in his monograph "Alalakh and Chronology" provided him with a gratefully accepted method of correlation with better known cultures in neighbouring lands.

At Alalakh (the Atchana mound) there were unearthed seven archæological levels of buildings, pottery, etc., and a trial pit has shown at least three more underneath and as yet unexcavated. Layer 7 has yielded an imposing city gate and a great palace built by Yarim Lim, king of Aleppo and overlord of Alalakh-according to Sidney Smith c. 1780-1730 B.c. It is contemporary, therefore, with the end of the Egyptian Twelfth Dynasty and the Middle Minoan period of Crete. Near the coast at Ras Shamra, Middle Minoan II sherds have been discovered in presumably contemporary levels but, of course, this does not itself prove direct contacts. No Cretan ware occurred at Alalakh; all was Asiatic (Khabur ware), and the types persisted down to level 5, c. 1483 B.c. During 1800-1500 B.d. Alalakh was thus predominantly Amorite. There is evidence (seal-impressions) that Egyptian political claims were recognized, but culturally the town looked eastwards. But while the influence of the West on Alalakh seems at this time to have been slight, Sir Leonard feels that the astonishing resemblance of the palace itself in its plan and construction to that of Knossos, not to mention the style of the frescoes found, suggests, even as Sir Arthur Evans hinted ("Palace of Minos", 2, 269) that migration of Asiatic people to Crete played a part in the rise of the culture there. He adds that the frescoes at Alalakh are at least a century older than their parallels at Knossos, so that "there can be little doubt as to the originating centre", and argues that North Syria was helping to build up in Crete that remarkable Minoan civilization which was later to have its repercussions in Asia. In the same way and on the same grounds of architectural resemblances, he suggests that Amorite influence affected the regions to the north, inspiring not only the late Syro-Hittite buildings of North Syria such as Sakje-Geuzi and Carchemish, but even the more distant Boghaz Keui in the Halys basin.

In levels 6 and 5 there are fewer remains. It would seem that the influence of Egypt disappeared-this was the period of the Hyksos domination there-but the Hittites to the north were becoming an organized power. It was a Hittite invasion of North Syria, conducted by Mursil I in 1595, that terminated the local phase represented by level 6. However, culturally Alalakh continued much as before until Thutmose III conquered the town in 1483. But the weakness of Egypt permitted the folk of the 6th level to be in closer relationship with southern Syria and Palestine, as is reflected in the types of pottery found.

Level 4, starting from the Egyptian campaign of 1483, comprises, in so far as its principal building is concerned, three phases, including the enlarged palace of Niqme-Pa, c. 1450, which take us down to 1370, when the Hittite king Suppiluliuma invaded North Syria and, after destroying the Mitanni kingdom, installed his son as king of Aleppo. The main feature of the pottery of level 4 is the prevalence of the Cypriote Bronze Age type. Gone is the old Khabur ware. The better local wares are now either plain burnished red, or have simple bands of colour. All have a distinctly Cypriote flavour. As the typical Cypriote 'milk bowl' actually occurs at Alalakh so early as level 6 (seventeenth century B.c.) and sherds resembling the Cypriote white slip ware have been 
unearthed from below level 7, once again Sir Leonard concludes that, throughout, the main influences flowed from the mainland to Cyprus and not vice versa. To this level, too, must be ascribed certain sculptures of Hittite type which were actually found, re-used, in level I. Sir Leonard sees in these the direct forerunners of the lions of early type at Carchemish and of the watergate reliefs of the same city. His argument is further supported by the finding of a bronze lion dagger, almost an exact parallel to the 'dagger god' represented in the Yasilikaya rock carvings. Niqme-Pa's palace has supplied one example of Lower Minoan II pottery, and another contemporary one with the familiar octopus pattern found in a private house. Ivory carvings, which are clearly copies of Egyptian prototypes of the time of Thutmose IV, occur, and contact with Egypt at this time seems to have been close.

The buildings of level 3 are few and poor. The period begins with Suppiluliuma's conquest of North Syria and lasts until 1285 B.c. Throughout this time Alalakh' was ruled by the Anatolian Hittites, which fact explains the difference at this period between it and Ugarit (Ras Shamra), which was only fifty miles away, for the latter did not fall under Hittite control. The influx of Egean settlers and others made of the Syrian coast town an outpost of Late Minoan II civilization, but only a very little Agean influence can be noted at Alalakh.

Level 2 is dated from about 1275 to 1220 B.c. The main interest here is the occurrence of a local Syrian (Mitanni) ware, the decoration of which is ornate with bold rosettes in white on a dark ground and animal and bird forms introduced. A development of this, apparently peculiar to Alalakh, has all-over designs in which the motifs are running water, elaborate stylized lotus plants, and the double axe. The connexion with the Cretan Middle Minoan III is indisputable, though no doubt an example of deferred inspiration.

With the fall of the Hittite power in 1220 B.c., Alalakh was more open to Agean influences. Nearly every grave in Level l contains a Mycenæan vase, and doubtless Ugarit was the connecting link. Then came the great movement of the 'Peoples of the Sea' who swept down, about 1190 B.c., through Anatolia and Syria and were only stopped by Ramses III on the borders of Egypt itself. Ugarit was destroyed, as was Alalakh, and neither site was ever again reoccupied.

To sum up, Sir Leonard Woolley considers that there is evidence for :

(1) "Direct contact with the Asiatic mainland influencing in or before the 18th century the development of the Cretan civilization."

(2) The existence in the Anatolian Hittite confederacy of an important element culturally if not racially akin to the Amorite population of northern Syria.

(3) A possible Asiatic origin of the Cyprus Bronze Age culture.

(4) Egyptian control of northern Syria in the Twelfth Dynasty with, later, a relation between the Hyksos culture and that of the Amk plain.

(5) Direct Late Minoan II and III influences on northern Syria.

(6) The development of Syro-Hittite art in northern Syria long before the beginning of the Syro-Hittite political period and of its kinship with the Hittite art of Anatolia.

\section{ASSOCIATION OF SCIENTIFIC WORKERS}

\section{MEDICAL SCIENCES COMMITTEE}

$\mathrm{A}^{\mathrm{T}}$ $\mathrm{T}$ a conference for workers in the medical sciences arranged by the Association of Scientific Workers, held on January 9 at the London School of Hygiene and Tropical Medicine, Dr. D. McClean (chairman) recalled that the Medica] Sciences Committee of the Association was elected in May, 1942, in an attempt to put into operation the policy of the Association in the medical sciences. That policy was the application of science for the benefit of the community and the raising of the status of the scientific worker. The responsibility for the application of medical science to public needs lies with medical scientists (not medical men alone) themselves ; means should therefore be provided whereby all medical scientists could consult on methods of improving their work and collaborate in the most effective way in pressing for its application in practice.

Mr. Ben Smith, industrial organizer of the Association of Scientific Workers, emphasized the necessity for organization of workers in the medical sciences if they wish to get their policies implemented. Any activity the object of which is to alter existing conditions is necessarily political in nature, and for political activity organization is essential.

Dr. J. H. Humphrey, speaking for the Industrial Health Sub-committee of the Association, said that owing to the increasing numbers of persons working in factories and the extreme specialization in the work, industrial hazards are becoming more complex and important, while the medical personnel available for their prevention and the treatment of their effects are inadequate. Work on industrial hazards was carried out before the War by the Industrial Health Research Board; during the War, the activities of this body have practically ceased, but partly owing to the efforts of the Association it has recently been resuscitated. The Physiological Society has circularized its members to discover whether physiologists are available for full-time or part-time work on industrial health problems. None were available for full-time work, few for part-time. Liaison with shop stewards has also proved very profitable, as workmen themselves have suggested problems for medical research which might otherwise have passed unnoticed. The main difficulty is less to obtain new knowledge than to get what is already well-known applied.

Dr. Yudkin directed attention to the unorganized nature of nutritional research and gave an account of the efforts of the Nutrition Sub-committee of the Association to obtain co-ordination of nutritional research by pressing for the formation of a Nutrition Council.

Dr. C. L. Oakley spoke on the difficulties experienced by research workers in discovering who are working in their own and closely related fields; ignorance of current and unpublished research leads to much duplication of work and waste of time and energy. The specialization of modern research work frequently requires collaboration between experts in various different techniques. Those who wished to collaborate should be encouraged, and for this purpose he suggested the formation of a central bureau at which research work could be registered in title, and from which information could be sent out to 